\title{
PENGGUNAAN APLIKASI ONLINE QUIZIZZ DALAM MENGANALISIS HASIL TES KOGNITIF SISWA PADA MATERI ENERGI
}

\author{
Lusiani \\ Akademi Maritim Nusantara \\ anilusi0287@gmail.com
}

\begin{abstract}
The purpose of this study was to analyze the results of students' cognitive tests on energy using the Quizizz application in online learning. This research method is in the form of survey research and literature review. Sampling was carried out using random sampling in order to obtain 28 vocational students in the physics subject matter of energy, but two of them experienced problems so that they could not take the test of learning outcomes in energy material. The analysis of cognitive test results is described quantitatively with descriptions of images and graphs of media Quizzes. The results showed that as many as 26 SMK students could answer questions correctly on the energy material in some of the questions presented. The analysis of the most correct answers and the fastest time to answer is in the fifth question, 25 correct answers are obtained within 2 seconds, while the least correct answers and the longest answer are in the tenth question with 8 correct answers within 16 seconds. Students can answer questions in the form of theory that are displayed in picture form, while students have difficulty answering questions in the form of mathematical calculations using certain formulas related to energy even though the pictures have been shown as a way to facilitate understanding of the questions. In conclusion, the use of the Quizizz application provides an idea to educators that the learning outcomes of students' cognitive tests can be easily obtained in a fast time to get an evaluation of learning outcomes, so it can be recommended as a medium for evaluating learning in various fields and various subject matter.
\end{abstract}

Keywords: Energy, Online Learning, Quizizz, Cognitive Tests

\begin{abstract}
Abstrak: Tujuan penelitian ini adalah untuk menganalisis hasil tes kognitif siswa materi energi menggunakan aplikasi Quizizz pada pembelajaran online. Metode penelitian ini berbentuk penelitian survei serta kajian literatur. Pengambilan sampel dilakukan menggunakan random sampling sehingga diperoleh 28 siswa SMK pada mata pelajaran Fisika materi energi, namun dua diantaranya mengalami kendala sehingga tidak dapat mengikuti tes hasil belajar materi energi. Analisis hasil tes kognitif dijabarkan secara kuantitatif dengan deskripsi gambar dan grafik media Quizizz. Hasil penelitian menunjukkan bahwa sebanyak 26 siswa/i SMK dapat menjawab pertanyaan dengan benar pada materi energi pada beberapa soal yang disajikan. Analisis jawaban benar paling banyak dan paling cepat waktu menjawabnya terdapat pada pertanyaan kelima, diperoleh 25 jawaban benar dalam waktu 2 detik, sedangkan jawaban benar paling sedikit dan paling lama waktu menjawabnya terdapat pada pertanyaan kesepuluh dengan 8 jawaban benar dalam waktu 16 detik. Siswa/i dapat menjawab pertanyaan berupa teori yang ditampilkan dalam bentuk gambar, sedangkan siswa/i mengalami kesulitan saat menjawab pertanyaan berupa perhitungan matematis dengan menggunakan rumus tertentu terkait energi walaupun sudah ditampilkan gambar sebagai cara mempermudah pemahaman soal. Simpulan, penggunaan aplikasi Quizizz memberikan gambaran kepada pendidik bahwa hasil belajar tes kognitif siswa/i dapat dengan mudah diperoleh dalam waktu yang cepat guna mendapatkan evaluasi hasil belajar, sehingga dapat direkomendasikan sebagai media untuk mengevaluasi pembelajaran pada berbagai bidang dan berbagai materi pelajaran.
\end{abstract}

Kata Kunci: Energi, Pembelajaran Online, Quizizz, Tes Kognitif

\section{PENDAHULUAN}

Selama masa pandemi Covid19 ini berbagai bidang dalam aspek kehidupan terkena dampaknya. Salah satunya yaitu bidang pendidikan, seperti pada jenjang perguruan tinggi yang harus dapat beradaptasi dengan pandemi ini dalam hal proses pembelajaran. Proses pembelajaran yang sebelumnya dilaksanakan melalui luring, kemudian dirubah melalui daring. Berbagai media digunakan dalam pembelajaran online (luring). Pendidik dan peserta didik 
harus mampu beradaptasi dan terbiasa dengan penggunaan teknologi informasi dalam berbagai media pembelajaran online yang digunakan. Hal ini bertujuan untuk tetap menjamin mutu hasil belajar siswa.

Berbagai media dapat digunakan saat kegiatan belajar mengajar online antara lain seperti media aplikasi Quizizz yang bisa dimanfaatkan untuk mengukur hasil belajar siswa sehingga dapat membantu pendidik mengetahui kemampuan kognitif peserta didik. Secara keseluruhan setiap bagian terdampak Covid-19, tidak terkecuali bidang pendidikan di berbagai tingkat antara lain tingkat dasar, menengah pertama, menangah atas serta perguruan tinggi. Berbagai efek tidak baik disebabkan peserta didik diharuskan belajar di rumah disebabkan proses pembelajaran secara langsung diganti melalui daring dalam rangka mengurangi penyebaran wabah Covid-19. Dalam kenyataannya sebagian besar peserta didik belum beradaptasi dengan sistem daring, hal tersebut pun terjadi dalam lingkup pendidik baik guru maupun dosen khususnya di berbagai daerah (Purwanto, 2020).

Kegiatan belajar mengajar yang menyenangkan bisa diciptakan dengan pemanfaatan berbagai macam model maupun metode pembelajaran atau menggunakan media pembelajaran yang menarik sehingga mampu membuat peserta didik semakin bersemangat belajar serta lebih mudah memahami materi. Pengembangan media pembelajaran melalui komputer atau Laptop serta Handphone maupun Smartphone, salah satunya melalui pemanfaatan game edukatif. Game edukatif masih belum familiar walaupun telah ada namun pemanfaatan sebagai media pembelajaran sangat kurang (Setiawan et al., 2019).
Berdasarkan hasil penelitian yang dilakukan oleh Setiawan et al., (2019)bahwa terjadi peningkatan yang signifikan pada hasil pengamatan keterampilan proses siswa saat proses kegiatan belajar mengajar yang mengimplementasikan Quizizz dalam menyelesaikan pertanyaan-pertanyaan terkait materi SPLTV metode eliminasi serta metode determinan.

Berdasarkan hasil penelitian Wibawa et al., (2019) diperoleh bahwa penggunaan aplikasi smartphone "kuis" sebagai media pembelajaran mampu memotivasi siswa agar berpartisipasi saat proses belajar mengajar, sehingga siswa bisa fokus serta memperluas penggunaan smartphone sebagai media belajar yang menyenangkan. Konsep belajar maksimum bisa memberikan efek terhadap nilai tambah hasil belajar siswa.

Setelah melakukan pengukuran
hasil belajar siswa melalui pemanfaatan media pembelajaran tertentu saat pandemi Covid-19 serta telah dilakukan kajian awal terkait analisis pengetahuan awal pada materi mekanika, maka peneliti tertarik untuk menganalisis hasil tes kognitif siswa materi energi menggunakan aplikasi quizizz pada pembelajaran online. Peneliti tertarik karena dengan aplikasi tersebut dapat memberikan gambaran hasil belajar siswa yang bisa dimanfaatkan untuk evaluasi terhadap penggunaan strategi, media maupun metode pembelajaran yang digunakan selama sistem online.

\section{LANDASAN TEORI}

Media pembelajaran online dipahami sebagai media yang lengkap dengan alat pengontrol yang mampu digunakan user yang mampu mengendalikan serta mengakses hal yang menjadi kebutuhan pengguna (Arnesti \& Hamid, 2015). 
Awal kemunculan multimedia adalah berperan sebagai pelengkap, namun pendidik dapat memanfaatkan multimedia untuk tujuan tertentu. Dalam hal ini, tidak ada persyaratan bagi pendidik maupun peserta didik dalam menggunakan level tersebut. Meskipun sebagai pilihan, pendidik yang menggunakan multimedia dengan tepat untuk mengajar peserta didik lalu memanfaatkan multimedia tersebut dengan benar tentunya akan mempunyai pengetahuan maupun wawasan tambahan.

Multimedia digunakan untuk melengkapi maupun mendukung teori yang disampaikan dalam kegiatan belajar mengajar yang diperoleh siswa saat di kelas. Multimedia ditujukan untuk penguatan (pengayaan) untuk partisipasi siswa saat pembelajaran.

Multimedia disebut sebagai program perbaikan di mana siswa yang mendapatkan kendala menguasai materi yang diajarkan pendidik di kelas diberi kesempatan untuk menggunakan multimedia yang dirancang khusus dengan tujuan agar siswa lebih mudah memahami hal-hal sebelumnya yang disampaikan pendidik dalam kelas (Wibawa et al., 2019).

Salah satu media evaluasi kegiatan belajar mengajar dengan basis E-Learning bisa menggunakan Quizizz. Media Quizizz ini dapat menyajikan data dan statistik terkait kinerja mahasiswa serta dapat mendownload statistic tersebut dalam bentuk Spreadsheet Excel. Pendidik mampu mengetahui total respon peserta didik. Penggunaan Quizizz. mempermudah guru maupun Dosen dalam melaksanakan evaluasi yang tidak terbatas ruang, tampilan menarik serta manajemen waktu yang disusun mengarahkan konsentrasi peserta didik secara runtut (Purba, 2019).

Salah satu faktor kesuksesan pada kegiatan belajar mengajar adalah berfungsinya media pembelajaran sebagai tempat menyampaikan pesan pembelajaran dari pusat belajar maupun pusat informasi kepada penerimanya. Hal ini terikat dengan peran guru. Kompetensi guru saat mengajarkan materi kepada siswa merupakan salah satu kondisi yang diharuskan sehingga dapat dijadikan bahan pertimbangan untuk terus dikembangkan dan dilanjutkan dengan menggunakan model serta media yang efektif serta efisien.

Kompetensi guru dalam penguasaan TIK dalam menghasilkan media pembelajaran yang dinilai masih kurang, perlu ditingkatkan dengan tujuan membuat kompetensi ini utama untuk pengembangan kompetensi bagi siswa dengan salah satunya diakomodir dengan peningkatan wawasan serta ketrampilan menciptakan media pembelajaran sesuai keperluan siswa peserta, yang dapat didukung dengan implementasi tugas serta fungsi tenaga fungsional Pengembang Teknologi Pembelajaran (PTP) saat fasilitasi peningkatan kompetensi PTK untuk menerapkan pembelajaran berbasis TIK (Aini, 2019).

Quizizz merupakan aplikasi pendidikan dengan basis game, yang mengarahkan kegiatan multi pemain menuju ruang kelas serta menjadikannya berada dalam kelas latihan interaktif serta menyenangkan. Murid bisa melaksanakan latihan di kelas dengan perangkat elektronik yang dimiliki. Quizizz berbeda dengan aplikasi lain yaitu mempunyai karakteristik permainan sejenis avatar, tema, serta musik menghibur saat kegiatan pembelajaran. Penggunaan Quizizz memungkinkan siswa dapat berkompetisi satu sama lain serta memberikan motivasi murid belajar. Murid menggunakan kuis di saat yang bersamaan dalam kelas serta mengetahui peringkat langsung pada 
papan peringkat. Guru atau Dosen bisa memantau proses serta mengunduh laporan saat kuis selesai, hal ini dilakukan dalam rangka mengevaluasi kinerja murid. Quizizz merupakan aplikasi yang membantu memacu motivasi serta meningkatkan konsentrasi murid (Purba, 2019).

Perkembangan teknologi telah terbukti memberikan pengaruh media pembelajaran yang dapat diaplikasikan di sekolah. Efek positif penggunaan teknologi dengan bermacam-macam pengembangan media mampu mendukung penambahan pemahaman serta keterampilan murid untuk memperoleh kompetensi belajar yang dituju. Prinsip belajar inovatif, kreatif, dan menyenangkan akan mampu terakomodasi melalui gaya belajar yang difasilitasi melalui audio, visual, dan kinestetik.

Peningkatan teknologi yang selalu digunakan secara berkelanjutan dapat menciptakan media pembelajaran yang efektif serta efisien dengan basis TIK, sehingga dapat dikembangkan sebuah media pembelajaran melalui penggunaan aplikasi online yakni Quizizz. Aplikasi tersebut belum familiar pada kalangan pendidik di Bengkulu dalam penggunaannya sebagai media pembelajaran berdasarkan pertanyaan penulis terhadap 50 pendidik di Bengkulu. Quizizz tersebut berisi materi pelajaran yang disusun dalam pertanyaan interaktif bermacammacam topik dalam beberapa jenjang mata pelajaran, serta lainnya dengan pilihan isi materi yang disusun sendiri oleh pendidik yang memiliki peran sebagai admin maupun pendesain yang tersimpan pada library kuis halaman home (Aini, 2019).

Media pembelajaran yang bisa disusun serta digunakan melalui aplikasi Quizizz berupa multimedia interaktif. Quizizz mempunyai kelebihan yang bisa digunakan untuk bahan evaluasi pembelajaran seperti adanya data serta statistik kinerja siswa yang hasilnya dapat menjadi bahan dalam evaluasi tindak lanjut kegiatan belajar mengajar. Fitur lain media ini digunakan untuk media belajar di rumah yakni pekerjaan rumah (PR) yang bisa memberikan kesempatan peserta didik dapat belajar pada luar kelas yakni dalam kelas virtual sekaligus dijadikan tempat belajar sambil bermain melalui media tersebut. Permainan yang kreatif, inovatif, menantang, serta menyenangkan dapat mennciptakan motivasi positif bagi keinginan belajar siswa (Aini, 2019).

Pemanfaatan Quizizz cukup mudah, kuis yang sudah dirancang bisa langsung ditambahkan pada Quizizz serta bisa ditentukan gambar, latar belakang atau opsi pilihannya. Kuis bisa dishare menggunakan kode pada peserta didik. Quizizz menyajikan data statistik berdasarkan hasil pengerjaan kuis oleh peserta didik yang bisa diunduh berupa spreadsheet Excel. Pemanfaatan Quizizz cukup luwes disebabkan ada manajemen waktu saat pelaksanaan kuis. Beberapa kemudahan serta kelebihan tersebut memungkinkan Quizizz sebagai media untuk analisis konsep pemahaman peserta didik pada materi gelombang mekanik (Yana et al., 2019).

Beberapa kelebihan penyajian soal menggunakan Quizizz adalah sebagai berikut: (1) lebih efisien disebabkan tanpa memakai kertas; (2) lebih efektif serta praktis saat merekam jawaban peserta didik secara otomatis, serta langsung terhitung melalui Microsoft Excel; (3) tidak menimbulkan kebosanan, lengkap dengan gambar yang memiliki warna serta bunyi (Yana et al., 2019). 


\section{METODE PENELITIAN}

Metode penelitian ini adalah survei serta kajian literatur. Waktu pelaksanaan penelitian pada bulan Januari 2020 dengan populasi sejumlah 55 siswa SMK di Cilacap, pengambilan sampel secara random sampling sejumlah 25 siswa SMK pada mata pelajaran Fisika materi Energi.

Pengambilan sampel dilakukan dalam lingkup Sekolah Menengah Kejuruan dikarenakan materi Energi terdapat pada kurikulum Sekolah Menengah Kejuruan. Pada kajian berikut, dianalisis data hasil belajar kognitif siswa yang didapatkan menggunakan instrumen berupa media quizizz materi Energi. Prosedur pengambilan data yaitu dengan menggunakan aplikasi Quizizz dengan sampel yang sama. Siswa/i SMK menjawab pertanyaan melalui aplikasi Quizizz. Data yang diperoleh kemudian dianalisis dengan deskripsi gambar dan grafik media. Analisis hasil tes kognitif dijabarkan secara kuantitatif dengan deskripsi gambar dan grafik media Quizizz.

\section{HASIL PENELITIAN}

Tampilan Soal Nomor 1 Materi Energi

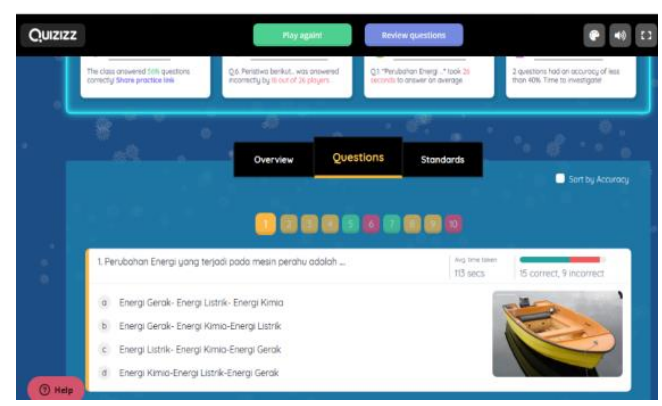

Gambar 1. $Q 1$ Energi
Tampilan Soal Nomor 2 dan 3 Materi Energi

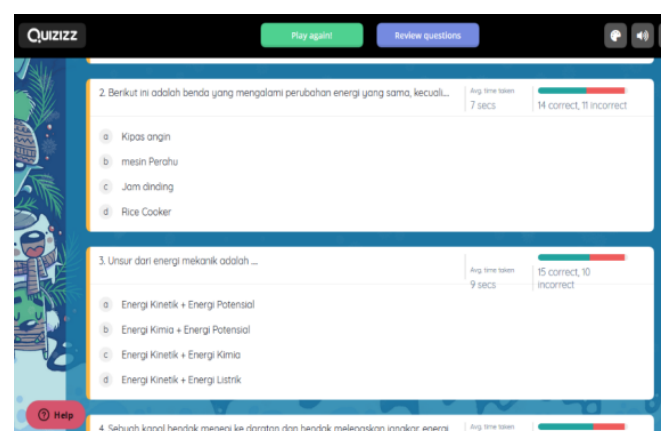

Gambar 2. $Q 1$ dan $Q 2$ Energi

Tampilan Soal Nomor 4 dan 5 Materi Energi

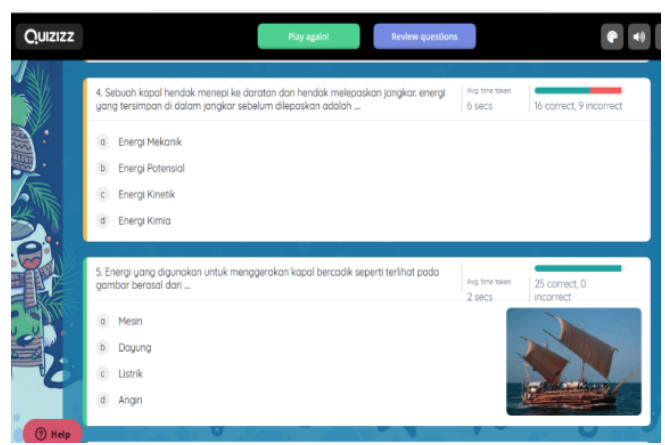

Gambar 3. $Q 4$ dan $Q 5$ Energi

Tampilan Soal Nomor 6 dan 7 Materi Energi

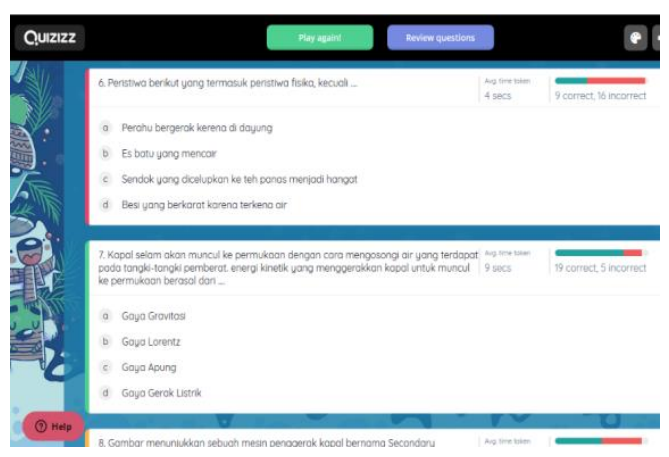

Gambar 4. $Q 6$ dan $Q 7$ Energi 
Tampilan Soal Nomor 8 dan 9 Materi Energi

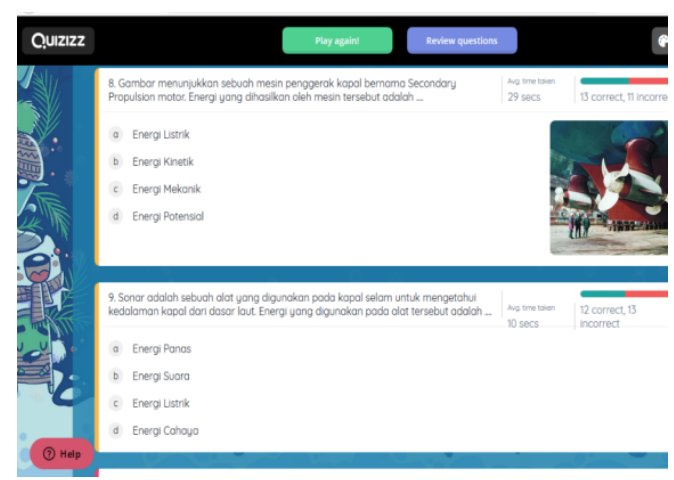

Gambar 5. $Q 8$ dan $Q 9$ Energi

\section{Tampilan Soal Nomor 10 Materi Energi}

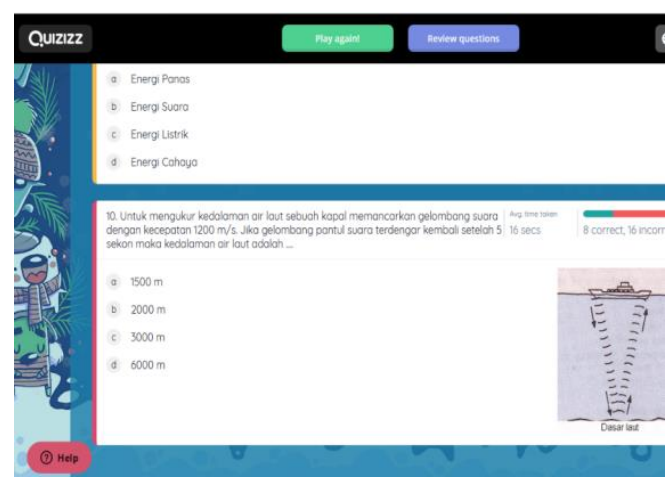

Gambar 6. $Q 10$ Energi

\section{Tampilan Result (1) Quizizz Materi Energi}

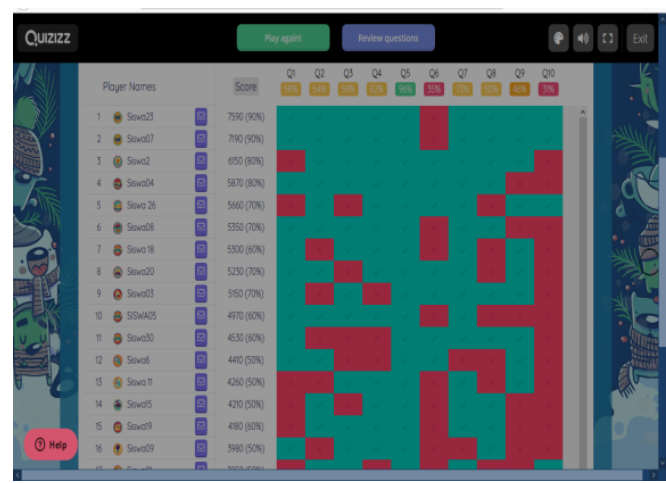

Gambar 7. Result (1) Quizizz Materi Energi

\section{Tampilan Result (2) Quizizz Materi Energi}

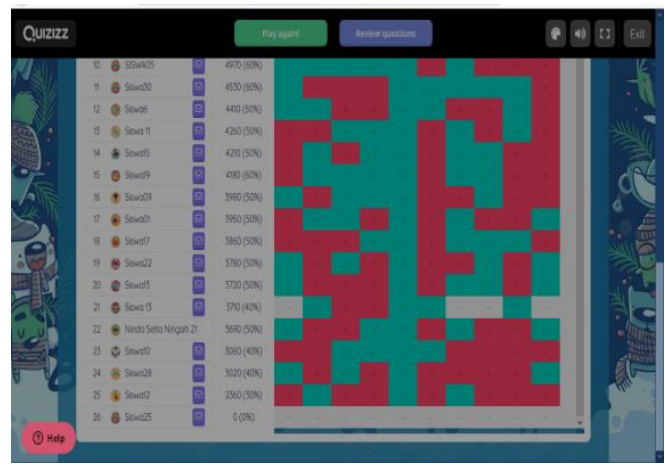

Gambar 8. Result (2) Quizizz Materi Energi

Analisis hasil tes kognitif siswa pada materi energi menggunakan aplikasi online Quizizz menunjukkan bahwa sebanyak 26 siswa/i SMK dapat menjawab pertanyaan dengan benar pada materi Energi pada beberapa soal yang disajikan. Analisis dilakukan di setiap pertanyaan. Pertanyaan pertama diperoleh 15 jawaban benar dalam waktu 113 detik. Pertanyaan kedua diperoleh 14 jawaban benar dalam waktu 7 detik. Pertanyaan ketiga diperoleh 15 jawaban benar dalam waktu 9 detik. Pertanyaan keempat diperoleh 16 jawaban benar dalam waktu 6 detik.

Selanjutnya, pertanyaan kelima diperoleh 25 jawaban benar dalam waktu 2 detik. Pertanyaan keenam diperoleh 9 jawaban benar dalam waktu 4 detik. Pertanyaan ketujuh diperoleh 19 jawaban benar dalam waktu 9 detik. Pertanyaan kedelapan diperoleh 13 jawaban benar dalam waktu 29 detik. Pertanyaan kesembilan diperoleh 12 jawaban benar dalam waktu 10 detik. Pertanyaan kesepuluh diperoleh 8 jawaban benar dalam waktu 16 detik.

Analisis jawaban benar paling banyak dan paling cepat waktu menjawabnya terdapat pada pertanyaan kelima diperoleh 25 jawaban benar dalam waktu 2 detik yaitu pada pertanyaan berisi energi 
yang digunakan untuk menggerakkan kapal bercadik seperti terlihat pada gambar berasal dari. Sedangkan jawaban benar paling sedikit dan paling lama waktu menjawabnya terdapat pada pertanyaan kesepuluh diperoleh 8 jawaban benar dalam waktu 16 detik yaitu pada pertanyaan untuk mengukur kedalaman air laut sebuah kapal memancarkan gelombang suara dengan kecepatan $1200 \mathrm{~m} / \mathrm{s}$, jika gelombang pantul suara terdengar kembali setelah 5 sekon maka kedalaman air laut adalah.

\section{PEMBAHASAN}

Berdasarkan hasil analisis,
diketahui bahwa siswa/i dapat menjawab pertanyaan berupa teori yang ditampilkan dalam bentuk gambar, sedangkan siswa/i mengalami kesulitan saat menjawab pertanyaan berupa perhitungan matematis dengan menggunakan rumus tertentu terkait energi walaupun sudah ditampilkan gambar sebagai cara mempermudah pemahaman soal. Hal tersebut dapat memberikan gambaran kepada pendidik bahwa hasil belajar tes kognitif siswa/i dapat dengan mudah diperoleh dalam waktu yang cepat untuk mendapatkan evaluasi hasil belajar. Dengan demikian, aplikasi ini dapat direkomendasikan sebagai media yang bisa digunakan dalam evaluasi pembelajaran pada berbagai bidang dan berbagai materi pelajaran.

Hasil ini sejalan dengan Aini (2019) bahwa salah satu media pembelajaran yang bisa dimanfaatkan dalam evaluasi hasil belajar siswa adalah aplikasi Quizizz yang merupakan multimedia interaktif secara virtual dengan beberapa keunggulan sebagai bahan evaluasi pembelajaran dengan tampilan data statistik kinerja siswa. Hasil evaluasi tersebut dapat digunakan sebagai bahan dalam evaluasi tindak lanjut pembelajaran ke depannya. Aplikasi ini mampu membangun inovasi baru dan dapat menumbuhkan motivasi belajar dalam diri siswa.

Wihartanti et al., (2019) menyatakan bahwa terdapat perbedaan yang signifikan antara kelas yang mengaplikasi Quizizz dibandingkan dengan kelas yang menggunakan model konvensional dalam proses pembelajarannya. Proses pembelajaran dengan aplikasi Quizizz juga mampu menumbuhkan kemampuan berpikir yang kritis.

Menurut Amornchewin (2018) media evaluasi online Quizizz mampu meminimalisir kelemahan yang terjadi saat evaluasi dilakukan dengan konvensional, sehingga hasil yang diperoleh lebih efisien. Aplikasi ini mampu meminimalisir human eror, soal dapat diacak secara cepat, sehingga mampu mengurangi kecurangan saat ujian dan hasil evaluasi dapat langsung dilihat, sehingga memudahkan guru untuk melakukan pengoreksian.

Hasil temuan yang sudah ada menunjukkan bahwa media evaluasi online Quizizz memenuhi kriteria fast respond evaluation yang merupakan sistem yang memberikan alternatif evaluasi dengan mengedepankan kecepatan dan ketepatan evaluasi hasil belajar kepada peserta didik. Oleh karena itu, diharapkan agar peserta didik dapat mengetahui bagian-bagian peralihan yang masih belum dimengerti sehingga mereka akan terpancing dalam mengetahui sejauh mana perkembangan pendidikannya.

Sistem fast respond evaluation juga memanfaatkan platform social media sebagai tools dalam memberikan informasi secepat mungkin kepada user melalui proses evaluasi yang terencana dan tersistematis. Proses ini berperan sebagai feedback kepada peserta didik dan juga sebagai upaya dalam memfasilitasi kecenderungan generasi 
yang menginginkan perkembangan evaluasinya lebih cepat dan mudah aksesnya. Selain itu, proses ini juga berperan dalam memberikan bentuk pengalaman belajar mengajar melalui pemanfaatan teknologi dalam menghasilkan sumber daya manusia yang siap pakai di era revolusi industri 4.0 (Firman et al., 2019).

\section{SIMPULAN}

Penggunaan aplikasi Quizizz dapat memberikan gambaran kepada pendidik bahwa dalam mengevaluasi hasil belajar tes kognitif siswa/i dapat diperoleh dengan mudah dan dalam waktu yang cepat, sehingga sangat direkomendasikan sebagai media pembelajaran online yang digunakan dalam evaluasi pembelajaran pada berbagai bidang dan berbagai materi pelajaran.

\section{DAFTAR PUSTAKA}

Aini, Y. I. (2019). Pemanfaatan Media Pembelajaran Quizizz untuk Pembelajaran Jenjang Pendidikan Dasar dan Menengah di Bengkulu. Jurnal Kependidikan, 2(25), 1-6

Amornchewin, R. (2018). The Development of SQL Language Skills in Data Definition and Data Manipulation Languages Using Exercises with Quizizz for Student's Learning Engagement. Indonesian Journal of Informatics Education, 2(2):85-90

Arnesti, N., \& Hamid, A. (2015). Penggunaan Media Pembelajaran Online-Offline dan Komunikasi Interpersonal terhadap Hasil Belajar Bahasa Inggris. Jurnal Teknologi Informasi \& Komunikasi dalam Pendidikan, 2(1), 85-99. https://doi.org/10.24114/jtikp.v $2 \mathrm{i} 1.3284$
Firman, F., Asfar, A. M. I. T., \& Suhardiman, S. (2019). Implementasi Media Pembelajaran Berbasis Android Sebagai Sistem Fast Respond Evaluation. Prosiding Seminar Nasional Penelitian \& Pengabdian Kepada Masyarakat 2019, 183-186

Purba, L. S. L. (2019). Peningkatan Konsentrasi Belajar Mahasiswa Melalui Pemanfaatan Evaluasi Pembelajaran Quizizz Pada Mata Kuliah Kimia Fisika I. Jurnal Dinamika Pendidikan, 12(1), 29. https://doi.org/10.33541/jdp.v1 2i1.1028

Purwanto, A., Pramono, R., Asbari, M., Hyun, C. C., Wijayanti, L. M., Putri, R. S., \& Santoso, P. D. (2020). Studi Eksploratif Dampak Pandemi COVID-19 terhadap Proses Pembelajaran Online di Sekolah Dasar. Journal of Education, Psychology and Counseling, 2(1), 1-12

Setiawan, A., Wigati, S., \& Sulistyaningsih, D. (2019). Implementasi Media Game Edukasi Quizizz untuk Meningkatkan Hasil Belajar Matematika Materi Sistem Persamaan Linear Tiga Variabel Kelas X IPA 7 SMA Negeri 15 Semarang Tahun Pelajaran 2019/2020. Seminar Nasional Edusainstek FMIPA UNIMUS 2019, 167-173

Wibawa, R. P., Astuti, R. I., \& Pangestu, B. A. (2019). Smartphone-Based Application "Quizizz" As A Learning Media. Dinamika Pendidikan, 14(2), 244-253. https://doi.org/10.15294/dp.v1 $4 \mathrm{i} 2.23359$

Wihartanti, L. V., Wibawa, R. P., Astuti, R. I., \& Pangestu, B. A. 
(2019). Penggunaan Aplikasi Quizizz Berbasis Smartphone dalam Membangun Kemampuan Berpikir Kritis Mahasiswa. Prosiding Seminar Nasional Pendidikan dan Pembelajaran 2019, 362-368

Yana, A. U., Antasari, L., \& Kurniawan, B. R. (2019).
Analisis Pemahaman Konsep Gelombang Mekanik Melalui Aplikasi Online Quizizz. Jurnal Pendidikan Sains Indonesia (Indonesian Journal of Science Education), 7(2), 143-152.

https://doi.org/10.24815/jpsi.v7 i2.14284 